\title{
Физика и технология полупроводниковых и гибридных наноструктур: тенденции развития, практические применения
}

Принц В.Я.

ИФП СО РАН, 630090, Новосибирск, пр. Ак. Лаврентьева, 13

DOI 10.34077/Semicond2019-35

В результате более чем 60 летнего развития кремниевая технология почти достигла предельных атомных размеров. В связи с этим для физиков и технологов 21 века вызовом является необходимость найти, исследовать и внедрить в промышленность новые материалы, с новыми функциональными свойствами, которые позволили бы продолжить прогресс в электронике, фотонике, информационных и коммуникационных технологиях. Более того, новые материалы должны обладать большим, чем кремний набором физических функциональных свойств, достаточных для создания нейроподобных вычислительных систем. Одной из областей исследования является окисная и коррелированная наноэлектроника [1]. Известно несколько десятков окислов, в том числе переходных металлов $\mathrm{VO}_{2}, \mathrm{ZnO}, \mathrm{Cu}_{2} \mathrm{O}, \mathrm{TiO} 2$ и т.д., которые являются полупроводниками, с уникальными важными для практических применений свойствами. В докладе представлен анализ физических свойств (электрических, оптических, магнитных, топологических) данных окислов, 2D полупроводниковых материалов $\mathrm{HfSe}_{2}, \mathrm{ZrSe}_{2} . \mathrm{CuCrO}_{2}, \mathrm{Ga}_{2} \mathrm{O}_{3}$, полупроводниковых перовскитов, новых Ван-дер-Ваальсовых гетероструктур на основе дихалькогенидов переходных металлов $\mathrm{MoS}_{2}$, $\mathrm{WS}_{2}, \mathrm{MoSe}_{2}$ и слоистых полупроводников $\mathrm{TaS}_{3}, \mathrm{TiS}_{3}$, перспективных для окисной электроники.

Bo второй части доклада приведены оригинальные результаты по исследованию одного из самых перспективных полупроводников - $\mathrm{VO}_{2}$, который относится к сильно коррелированным электронным материалам. При фазовом переходе полупроводник-металл его проводимость меняется до $10^{5}$ раз, наблюдается также рекордное изменение коэффициента преломления $(\Delta \mathrm{n}>1)$. Известны структурные и электронные фазовые переходы. Рекордно малое время переключения 26 фемтосекунд (переход Мотта-Хаббарда). Наиболее ярко свойства $\mathrm{VO}_{2}$ проявляются в монокристаллических нанокристаллах. Нам удалось впервые синтезировать упорядоченные массивы монокристаллических $\mathrm{VO}_{2}$ нанонитей [2]. Такие массивы могут рассматриваться как законченные интеллектуальные устройства для управления оптическим излучением (фотонные кристаллы, метаматериалы). Важно, что предложенный подход стыкуется с кремниевой технологией. В работе [3] предложен новый подход в формировании $\mathrm{VO}_{2}$ наноэлектроники, достигнуты рекордно малые энергии для электрических переключений. Приведены достижения в области формирования 3D наноструктур. На основе полученных результатов обсуждаются перспективы формирования нейроморфных вычислительных систем.

Исследование выполнено за счет гранта Российского научного фонда (проект № 18-19-00694).

[1] Colla M. et al, Appl. Surf. Scien. 482, 1-93, (2019).

[2] Mutilin S. V., Prinz V. Ya., Seleznev V. A., Yakovkina L. V. Appl. Phys. Lett. 113, 043101 (2018).

[3] Prinz V.Ya., Mutilin S.V., Yakovkina L.V., Gutakovskii A.K., Komonov A.I., Nanoscale (2019) 